\title{
The Development and Inheritance of National Music in College Music Education in the Multiculturalism Background
}

\author{
Jiayin Li ${ }^{a}$ \\ Zhejiang Conservatory of Music, No.1 Zhe Yin Road. Hangzhou 310000, China \\ a jiayin_li@hotmail.com
}

Keywords: Multiculturalism, colleges, ethnic music, teaching.

\begin{abstract}
China is composed of fifty-six different nationalities. The development and inheritance of minority traditional music cultures play an important role in the composition of the music of the Chinese nation. For thousands of years, various ethnic cultures have been created. The development of diverse ethnic music and different ethnic music has formed a diversified impact. How to protect and pass on ethnic music in colleges and universities in a multicultural context, and at the same time effectively protect them in daily teaching It is an important topic for music teaching in colleges and universities.
\end{abstract}

\section{Introduction}

In China, the country has 56 ethnic groups, ethnic minorities have more than 100 million people, accounting for $8.41 \%$ of the country's total population, and ethnic autonomous areas account for $64 \%$ of the country's total area. Due to the geographical environment, cultural background, production and living customs, aesthetic awareness, and other reasons, Chinese ethnic minority music presents various characteristics. Ethnic music is a concept with rich connotation and wide coverage, including traditional music as well as modern music [1]; it includes both Han music and ethnic music. Together with the Han nationality, ethnic minorities in China have jointly created a rich and colorful music culture. Only the folk songs are diversified and have endless charm. The representative here is only one of them. These folk songs of ethnic minorities blend in with their colorful cultures and add an incomparable charm to folk songs. However, in today dramatic social changes, the survival of ethnic minority music cannot but arouse our worries. Under the multicultural background of the need for the inheritance and development of national music in college music education, the inheritance of ethnic music in college music education and Development has important practical significance. The mufti-cultural music of the world and our country's national music culture can promote each other and develop together. Music is also one of the important windows for China to go to the world stage [2].

\section{The Importance of Teaching Ethnic Music in Colleges and Universities}

\subsection{Urgency of Inheritance and Development of National Music in Colleges and Universities}

Under the impact of a diversified culture in the world, our national music has been marginalized. Especially under the erroneous influence of the "European and American music culture center theory", our country's national music is facing a crisis and is experiencing the challenge of being marginalized and assimilated by European and American music. For a period, the enthusiasm of the Chinese society for the study and appreciation of ethnic music was not high, which caused great obstacles to the inheritance and development of national music. Colleges and universities are an important place for the transmission of fresh blood in our country and are the first line of the development of our country's national music [3]. However, the status of national music education in colleges and universities in our country is not optimistic. For example, in the construction of teachers in universities in our country, the order of professional requirements of music teachers is roughly piano, vocal music, music theory, sociologist, and harmony, etc., and ethnic music teachers are in a situation of marginalization [4]. Culture is the root of the Chinese nation's foothold in the world's national forests, and traditional 
music is an important part of our country's culture. Under the impact of mufti-cultural, the inheritance and development of the national music education in colleges and universities in our country is very urgent.

\subsection{National Music Education in Colleges and Universities Has Important Role in the Construction of Spiritual Civilization}

Music is one of the important tools for expressing expression in people's daily life. In the long history of our country, national music reflects people's living customs, aesthetic values, and thoughts and feelings at various historical stages. In our country's higher education system, the spiritual civilization construction of national music cannot be ignored [5]. In the process of learning national music, students can appreciate the essence of our country's traditional culture, accept the influence of excellent emotions, and inspire students' national consciousness. The process of learning national music is to cultivate the process of patriotism. Under the current multicultural background, national music education is an important entry point for colleges and universities to cultivate students' correct world outlook and values, and it has the irreplaceable role of other disciplines [6].

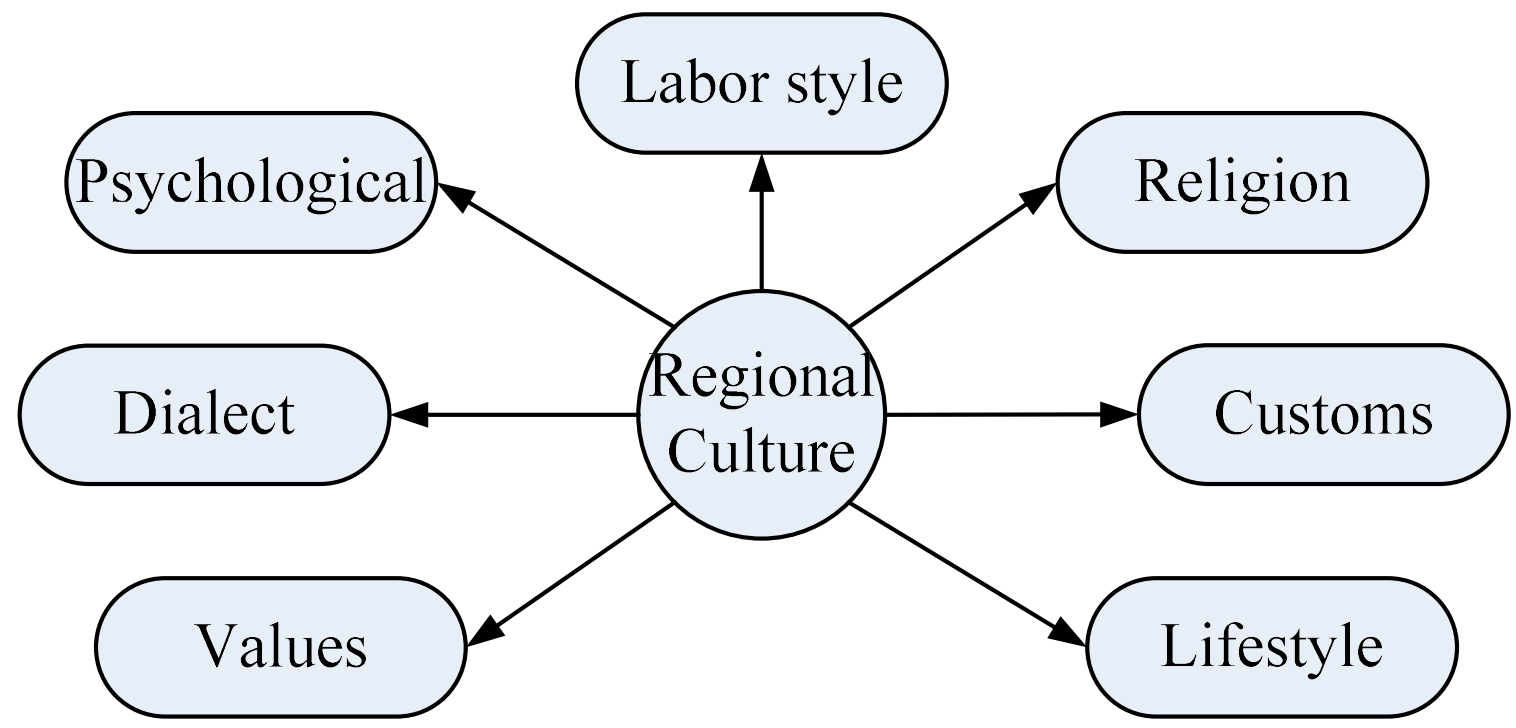

Fig. 1. National Music Development in the Background of Diversification

\section{Status of Development of National Music in Colleges and Universities in the Background of Multiculturalism}

Music is an artistic expression of emotional transmission. It affects the public's sense of hearing and enables people to enjoy the beauty. Music teaching is the main way to achieve academic quality education in colleges, and national music education is the point of college music teaching. Has the following three aspects of value performance:

\subsection{The Value of Multiculturalism in College Music Teaching}

The first is the value of emotional art. Music contains rich emotional art and plays an important role in purifying students' hearts and cultivating their sentiments. The development of China's national music has a long history. Different nationalities have formed different forms of music with different emotions in different periods. The integration of national music into college music teaching can strengthen students' emotional experience and cultivate their patriotism. The second is to realize the inheritance value of national culture. Music is an important form of culture. The national music has formed a unique cultural form in the development of the millennium. It has achieved the perfect integration of traditional culture and music. The construction of national music courses in colleges and universities is The effective way to promote and inherit my traditional culture.

Finally, the national music also has the value of social communication. Different national music are different in their expressions and styles. The colleges and universities in the implementation of 
national music teaching effectively achieved the exchange and development of various national music, and achieved the cross-cultural Exchanges can effectively strengthen the cohesion among all ethnic groups and promote the stable and harmonious development of our country's society.

\subsection{The Status of the Development of National Music in Universities}

At present, the development of the national music teaching in colleges and universities in our country is slow. There are still many problems in the process of its construction and development. On the one hand, college music teachers lack the correct understanding of the national music teaching, and college education system is influenced by western countries. The construction tends to western music, while the lack of professional and systematic national music teaching system for the traditional ethnic music education of the country leads to students' lack of understanding of the national music culture. In addition, the teaching content of college music teachers also tends to western music, which is influenced by the thinking of western music teaching and ignores the teaching of Chinese folk music. On the other hand, the enthusiasm of college students for national music learning is not high, and there is a lack of interest in learning. Enthusiasm and enthusiasm, the relatively boring content of ethnic music teaching materials and the single teaching methods of teachers are all factors that affect the effective development of college music education.

\subsection{Insufficient Attention to Ethnic Music}

Through the study of the history of national music in different countries. In the exploration of modern and contemporary history, non-western ethnic traditional music has been influenced by "westernization" [7]. National music is facing the status of the survival crisis and recognizes the importance of national music protection. We paid attention to and paid attention to folk music collection and recording methods and advocated respecting ethnic music in multicultural music education. From the background of cultural globalization corresponding to the globalization of the world economy. With respect to the starting point of reciprocal exchanges of music culture with various peoples of the world, and important components of ethnic culture, it has been found that ethnic cultural individuality, differences, and characteristics are important prerequisites for the equal exchange and dialogue with the music cultures of all ethnic groups in the world. It is the creativity of individuality and society. "The basic source of continuous development of creativity" pays attention to the situation in which "China lacks understanding of the world and the world lacks understanding of China." At present, the world's national music provides suggestions for the curriculum setting and the limitations of learning objects in China. In the process of multicultural music education, the main concerns remain in a relatively small scope. Whether it is teaching materials, curriculum issues, or national music issues, it can only be seen as a part of the construction and implementation of multicultural music education. It is also possible to reflect the sexual and deeper implications of this educational philosophy from a broader perspective.

\section{The Way of Inheriting National Music in Colleges and Universities under the Background of Multiculturalism}

\subsection{Establishing a Diversified Turning Mechanism of National Music Education}

The Chinese Music Education Association confirmed in the "Music Policy of the World Culture" that the core of the theory of world music education is cultural pluralism, and advocates that "music education should respect, absorb and accept the music of different forms and styles of all ethnic groups in the world most widely." Tradition has placed music education within the category of universality in the world." In the process of implementing multicultural music education, it is very important to grasp and handle the relationship between Chinese music and foreign music, Han music and ethnic minority music, European music and other countries' music and form, technology and culture. For a long time, European and American classical music traditions have played an important role in the development of world music and formed the concept of "universality of western music". This concept has had a certain influence on China's music education, which is reflected in the curriculum setting and the writing and use of teaching materials. The curriculum of music education 
major in China's colleges and universities is mostly based on the European music curriculum and follows the teaching model of the former Soviet Union. The nationality of music education is not strong. In this situation, the training mode of music education major in colleges and universities needs a new reform and exploration based on the needs of the development and dissemination of national music culture.

\subsection{Build a Curriculum System Based on Local Music Education and Supplemented by World Music Education}

Multicultural music education means that music is a kind of culture and it is a part of the national culture as a whole. It is regional and contemporary. Cultures of different ethnic groups and different groups should be respected and inherited. The Chinese music culture itself is formed by the fusion and co-construction of different national music cultures. It is the crystallization of mufti-cultural music and reflects the distinct mufti-cultural characteristics of music. Therefore, when conducting multicultural music education and teaching, we must first fully guarantee the implementation of the local music culture (especially minority music) curriculum, increase the development and use of the local music curriculum, and build the integration of the local music education and the world music education. New curriculum system.

\subsection{Building the Basic Course of National Music in Colleges and Universities}

China has a wide geographical area and many nationalities. The basic music curriculum should be based on the principle of curriculum development in our country. The three-level curriculum development system should be implemented: First, the national curriculum system, the second is the local curriculum system, and the third is the school-based curriculum system. The music major of Michelangelo University's College of the Arts adopts the "re-foundation, strong practice" training model, based on classroom teaching and artistic practice, and uses basic education and professional education as a platform to strengthen basic training. At the same time, professional instructional elective courses and professional elective courses are combined to carry out practical teaching activities to cultivate applied-type and compound music talents with strong musical theory abilities and professional basic skills. The college has set up a theory teaching link in the curriculum setting, that is, through the teaching of subject basic courses and professional compulsory courses, students can build a basic music theory knowledge system, a professional knowledge system, and a music history theory knowledge system. The practical teaching link, through the teaching of professional instructional modules, professional elective courses, and professional practice courses, cultivates the practical ability and comprehensive professional quality required for students to perform professional performances. The entrepreneurship education link, through entrepreneurship education learning and practice, enables students to carry out innovative activities in all aspects and from multiple perspectives to guide students in their entrepreneurial and creative thinking. In the compulsory courses and professional elective courses.

\subsection{Give Play to the Advantages of the Region and Develop Cultural and Cultural Resources for Ethnic Minorities in the Region}

Music culture is a cultural form that expresses human thoughts in musical language. Therefore, it must be influenced by the traditional culture of the nation and has distinctive national characteristics. It is necessary to incorporate ethnic folk music into the music education curriculum in colleges and universities to visually, auditor and sensually allow students to personally experience the ethos of the national music culture, so as to strengthen the music students' sense of identity, belonging and national pride in the national music. Michelangelo University is located in Michelangelo Province. Michelangelo Province is a region where many ethnic minorities live together, such as Manchu, Korean, Hui, Mongolian, Darfur, Orogeny, Chez, Gibe, and Kirghiz. In the course of the long process of continuous integration, assimilation, and survival and reproduction, these ethnic minorities have gradually formed a variety of cultures with rich local characteristics and distinctive ethnic styles. These ethnic cultures have distinctive regional and ethnic blends, and thus form the folk, folk, and national music cultures of various ethnic minorities [8]. 


\subsection{Development of National Music Education Policy Support}

In order to give full play to geographical advantages and develop minority music resources in Michelangelo, schools should provide support in terms of policies and funding. School music teachers and students can be organized to practice ethnic activities such as collecting winds in minority ethnic groups in the province each year. Teachers guide students to Michelangelo The artistic characteristics of ethnic folk music are analyzed and researched from multiple perspectives. From a mufti-perspective, multi-user, and stereoscopic perspective, the study is based on the more familiar existing Michelangelo folk music and related background materials. From the perspective of musical morphology, we study the overall style of ethnic folk music, and integrate the traditional folk music elements formed by the local ethnic traditional musical elements. From the point of view of musical geography, this paper studies the geographical attributes of minority music culture and the cultural characteristics of northern ethnic minority costumes. From the perspective of the spread of music, the study of the folk music of Michelangelo and the ancestral homes of the immigrants from Shannon, Hebe, and Russia, as well as the integration and influence with the surrounding cultures, has resulted in the formation of a localized minority music culture. This organized and purposeful investigation and study can enable students to better explore the cultural culture of ethnic minorities in Michelangelo Province, such as the production of folk songs, the status, the contents of folk songs, the form and style of singing, and then collect the collected music materials. The multimedia courseware and teaching materials made of sound, images, and diagrams were combined, and some of the detailed research activities were recorded and compiled into CD-ROM and selected in books and textbooks. These precious resources were then inherited and developed.

\section{The Music Education in Colleges and Universities Urgently Needs to Strengthen the Minority Musical Culture in the New Situation}

\subsection{The Needs of Excellent Ethnic Cultural Heritages}

With the advent of the modernization tide, the situation in the ethnic minority areas has been gradually broken down, and people's ways of thinking, values, codes of conduct and customs have all changed dramatically. Especially since the 1990s, young people in rural areas have gone out to work. Under the drive of the influence and interests of the colorful world, values have changed significantly. Some minority folk songs face a huge crisis of survival. The specific performances are as follows: First, the ecological environment of minority music is seriously damaged; second, the aesthetics and values have changed greatly; third, the national language gradually disappears. The need for the rise of multicultural music education Meta-cultural education is a hot topic of education in the world. It is a theoretical trend and a profound revolution. With the development of global economic and cultural globalization becoming more diversified, multicultural education and even multicultural music education have become new content and new perspectives of current education development. By correctly understanding the concept of multicultural education in order to understand multiculturalism cannot be applied mechanically, by folk music teaching, let the students vision, enhance mutual understanding and communication between different ethnic groups, establish a national self-confidence, enhance national pride, national culture of Cultural feelings. 


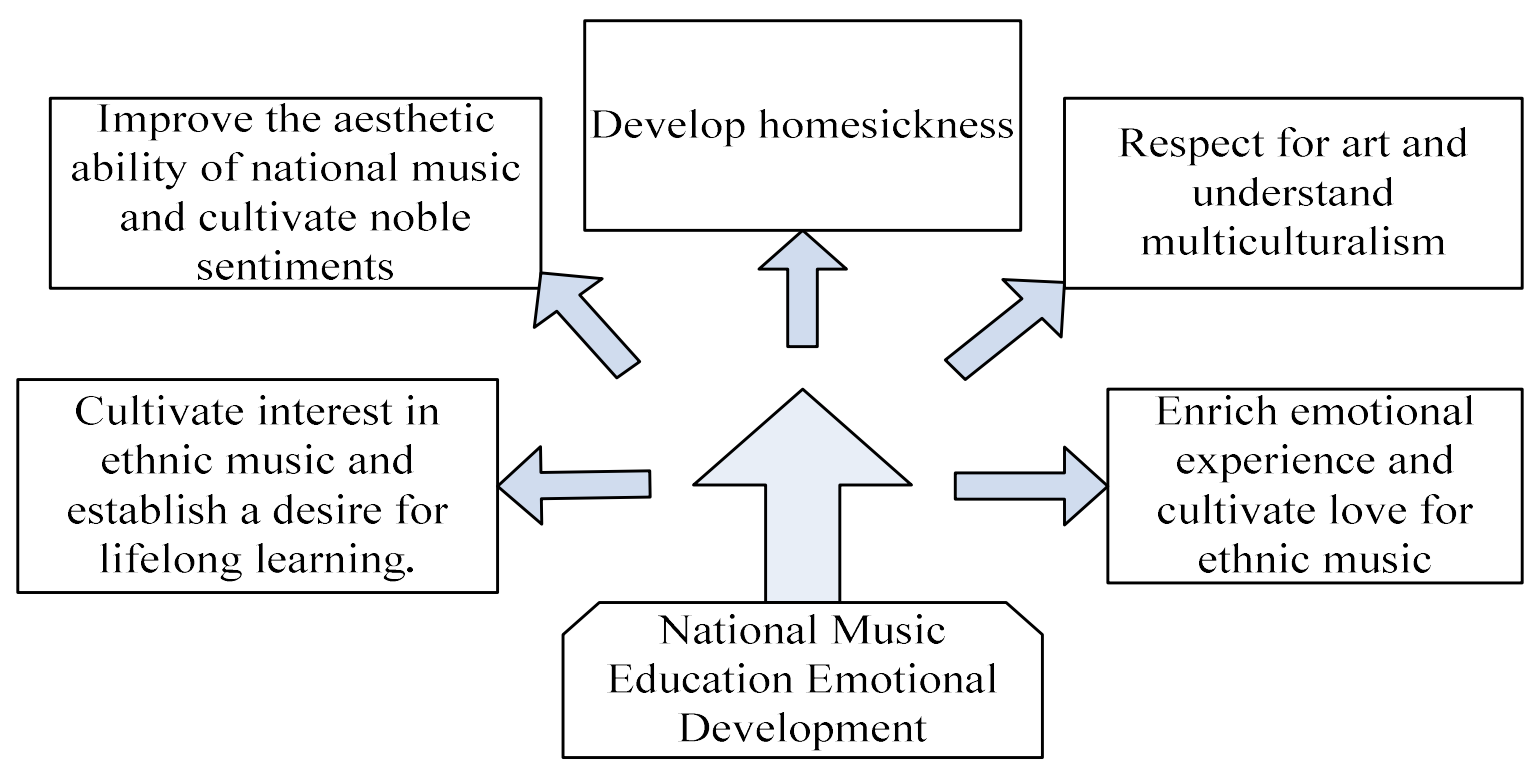

Fig. 2. Establishing a diversified steering system for national music education

China is also a country with a "multicultural music culture". However, in our schools at all levels, we still rarely include Chinese minority music as a basic course for music education. The lack of Chinese multicultural music education is not only extremely imperfect for the world's multicultural music education, but also may have a negative impact on the development of Chinese music. Therefore, the rise in the world's diverse music education and the rapid development of today, the national college music education should be strengthened teaching music culture of Chinese minorities, to make it into the world multicultural music education system as soon as possible, which has become an integral part.

\section{Conclusion}

In summary, under the current situation of increasingly diversified cultural development, China's traditional ethnic music is facing great opportunities and challenges. The national music's emotional and artistic value, cultural heritage value, and social communication value play an important role. to strengthen the construction of folk music courses, breaking the traditional teaching philosophy, innovative teaching ideas and teaching mode, and countless music teaching activities to enhance and students interact and inspire students to learn folk music interest and enthusiasm, thus achieving our national the promotion and inheritance of music.

\section{References}

[1]. Guan Jianhua, et al. Music, cross-cultural communication and multicultural music, education. Chinese Music. Vol. 2 (2003) No. 12, p. 113-115.

[2]. Wei Huang, et al. Cultural Reflection on Multicultural Music Education. Voice of Music, Research Vol.6 (2005) No. 8, p. 42-48.

[3]. Chen Yaxian, et al. on the Relationship between Musical Culture and Musical Education-Concurrently on the Culture of Musical Inheritance and the Inheritance of Musical Culture. Journal of Southwest University for Nationalities (Humanities and Social Science Edition) Vol. 13 (2013) No. 7, p. 321-325.

[4]. Yang Xiao. Cross R, et al.: Three Horizons of Cognitive "Multicultural Music Education" Reading "The Translation of World Music and Multicultural Classics". Music exploration, Vol. 7 (2003) No. 2, p. 43-45. 
[5]. H. Spears, Yang Hong, et al. A Multicultural Model of Music and Education: Dutch World Music, Teaching]. Chinese music, "Compilation Highlights" Vol. 9 (2015) No. 2, p.73-76.

[6]. Kong Yilong., et al. American Multiculturalism, Education Review. Symphony. 1999) No. 7, p. 32-37.

[7]. Chen Fang, et al. American Music Education in a Multicultural Background. Tianfu new theory, Vol. 1 (2014) No. 9, p. 128-132.

[8]. Guan Jianhua, et al. Cultural Strategy and Multicultural Music in the World, Reflections on Education. Chinese music, Vol.9 (2011) No. 10, p. 177-182. 